\title{
IAMJ
}

INTERNATIONAL

AYURVEDIC

MEDICAL JOURNAL

ISSN: 23205091

Impact Factor: 5.344

\section{AYURVEDIC CONCEPT OF KNOWING UNKNOWN DISEASE (ANUKTA VYADHI) W.S.R. TO THALASSEMIA}

\section{Kalpana Ladvikar}

Professor Department of Kaumarbhrutya,

Dr. R. Gode Ayurveda College and Research Centre, Amravati, Maharashtra, India

Corresponding Author: kalpanaladvikar@yahoo.com

\section{https:// doi.org/ $10.46607 /$ iamj5008102020}

(Published online: October 2020)

Open Access

(C) International Ayurvedic Medical Journal, India 2020

Article Received: 08/10/2020 - Peer Reviewed: 10/10/2020 - Accepted for Publication: 11/10/2020

\section{Check for updates}

\section{ABSTRACT}

Thalassemia is the most common genetic disorder resulting from abnormality of Globin chain. It is the worldwide problem of today's era and until no answer to any medical science. It is the challenging disorder for the scientist. The nature of the disease is genetic regarding this so many literatures available in the modern science but in Ayurveda has no answer for this disease. To add the new concept of disease Thalassemia (Anukta Vyadhi In Ayurveda), aim of study is to understand the unknown disease, the concept of Beeja, Beejabhaga and Beejabhagavayava should be clear because of its genetic nature of thalassemia. Charaka mentioned Aptopadesha method of examination, we can acquire knowledge as described by wise men, or Apta, use to understand a disease:

Keywords: Thalassemia, Pandu, Aptopadesha Pramana, Anukta Vyadhi

\section{INTRODUCTION}

Thalassemia is the most common inherited single gene disorder in the world. A systematic approach should be implemented for proper analysis of a disease process. The nature of the disease is genetic regarding this so many literatures available in the modern science but in Ayurveda has no answer for this disease.
The Beeja Dosha concept of genetic diseases was established very clear in the ancient time and the disease mentioned in the classics. It is one kind of Raktaja Vyadhis, and these are Tridoshaja, but among the Tridoshas, mainly Pitta is predominant, in Rakta Dushti as maximum. Nidanas for Rakta Dushti are 
Pitta Prakopajanya and the Pitta and Rakta have similar properties and site, so as Pitta gets vitiated, Rakta also becomes vitiated itself. Such disease is classified under Asadhya Vydhi. Asadhya nature of genetic disease already mentioned in Ayurvedic classics about Kulaja Vikara) and this disease can be managed by only Nidana Parivarjana (Carrier screening), Pathyabhyasa and by the Rasayana drugs which protect them from the complications. The methodology of understanding an unknown disease has been described in Charaka Samhita based on Aptopadesha Pramana. These are ${ }^{1}$

- Prakopanam: provoking factors, viz. process of the vitiation of the Doshas

- Yoni: Source of Doshas

- Uthanam: onset of a disease

- Atmanam: The cardinal sign and symptoms.

- Adhishthanam: Site, which could be the body or the mind or both

- Vedanam: signs and symptoms

- Sansthanam (location): Amashaya, Pakwashaya, Avayava Vishesha, or in micro channels

- Shabda, Sparsha, Rupa, Rasa, Gandham (five senses): Altered sensorium.

- Updravam: Complications

- Vriddhi Sthana Kshayam (Increased, decreased, balanced): Whether dosha, dhatu and mala are increased, decreased, or in balance

- Udarakam: Prognosis

- Namanam: Nomenclature

- Pravritti: Indicated treatment

- Nivritti: Contraindication

Aptopadesha Pramana in relation to Beej dosha:

1. Prakopanam: The word Prakopanam implies the Hetu for the vitiation of Doshas. The factors by which the imbalance of Doshic status is triggered will be coming under this heading. The prime agent for the change in homeostasis is the Ahita Sevana of Ahara or Vihara. In Astanga Hridaya which clear that the reason behind the Beeja Dushti depend on improper diet pattern of mother and father (Beejataptistu Matripitraapcharatah) or it may be due to Daiva prakopa which leads to Sannipata and diseases originate. ${ }^{2}$ The causative factor of disease Thalassemia is either defective gene or deletion of gene that responsible for the formation of hemoglobin.

2. Yoni: Yoni denotes Moolabhoota of a disease. Moolakarana of Thalassemia is Beeja Dushti. Here the Beeja denote Shukra and Shonita. ${ }^{3}$ The seeds of Shukra and Artava have chromosomes with genes representing the future organs to be developed. These are described as a Beeja (Sperm/ovum), Beejabhaga (Chromosomes), \& Beejabhagavayava (Genes) in Ayurveda. ${ }^{4}$

3. Utthanam: Due to Anuchita Ahara - Vihara of the parents Doshas predominantly Vata and Pitta vitiated and circulating throughout the body and at the cellular level mutate the genetic code of cell that's why normal functioning of that Dhatu will be altered, either leading to its destruction or abnormality. Changes in the Prakriti of Dhatu results of Dhatu Vikriti. (Ch.Sha.6/18). Thalassemia onset generally occurs from 6-24 months of age. The severe anemia requires systematic transfusions to maintain $\mathrm{Hb}$ levels above the range of $90-100 \mathrm{~g} / \mathrm{L}$ and to allow normal activity. ${ }^{5}$

4. Atmanam: Pratyatmalinga of disease is known as its Swaroopa. The main symptom of Thalassemia is Panduta. This is the pratyatmalinga of Thalassemia where as Pandubhava is invariable feature mentioned in Pandu Roga. Second main feature of Thalassemia is Alparaktata ( $\mathrm{Hb} \%$ decreases).

Table 1: Clinical features of Thalassemia similar to Pandu

\begin{tabular}{|l|l|}
\hline Thalassemia $^{6}$ & Pandu \\
\hline Pallor & Twak Pandutva \\
Reduction in $\mathrm{Hb} \mathrm{gm} \mathrm{\%}$ & Alparaktata \\
General weakness & Daurbalya \\
Dyspnea on exertion & Arohaneayasa \\
\hline
\end{tabular}




\begin{tabular}{l|l}
\hline Palpitation & Hridyaspandana \\
Pyrexia & Jwara \\
Anorexia, Dysphagia & Aruchi, Annadwesha \\
Loss of appetite & Kshudamandya \\
Headache & Shirahshula \\
General Bodyache & Angamarda, Gatrashula \\
\hline
\end{tabular}

5.Adhisttanam: The diseases may have their locus either in the Sareera or Mana. Adhistthana implies the main site of affliction. In Thalassemia the prime center of affliction is Beejabhagavayava (gene), which is responsible for the formation of Rakta Dhatu. Thalassemia syndromes are among the most common. Normal adult hemoglobin produced after birth (hemoglobin A $[\mathrm{HbA}]$ ) consists of a heme molecule linked to two $\alpha$-globin and two $\beta$-globin chains $(\alpha 2 \beta 2)$, with $\alpha$-globin chain production dependent on four genes on chromosome 16, and $\beta$-globin chain production arising from two genes on chromosome 11 . Deletions or mutations of one or more of these genes so that the rate of production of $\alpha$ - or $\beta$-globin chains is reduced results in alpha thalassemia or beta thalassemia, respectively. ${ }^{7}$

6.Vedanam: Vedanam denotes knowledge. Here it can be applied for the various diagnostic tests for Thalassemia. The diagnostic methods in Ayurveda are by means of Shabda Sparsha, Rupa, Rasa, Gandha i.e. Prathyaksha Pariksha and Anumana Pariksha which includes the provisional diagnosis. Thalassemia profile that includes CBC preferably on cell counter, peripheral smear, $\mathrm{HbF} \& \mathrm{HbA} 2$ estimation (quantitative), $\mathrm{Hb}$ electrophoresis or $\mathrm{Hb} \mathrm{HPLC}^{8}$ Iron studies and serum ferritin wherever required. All these tests should be undertaken before the first transfusion.

7. Samsthanam: Samsthana refers to the clinical manifestations of the disease. At this stage, Dosha Dushya Sammurchana would have completed and onset of disease would have commenced. The specialty of Thalassemia is that its progression adversely involves almost all the systemic processes. Thence the various symptoms may appear and persist throughout the lifetime one after another.
8. Upadravam: Upadrava is a disease produced after the formation of main disease and is dependent on the main disease whether Upadrava is major or minor. it is a secondary complication, produced by same Dosha that is responsible for formation of main disease. Thalassemia syndrome followed by a spectrum of diseases after a period of clinical latency. Complications are still common and include heart disease (heart failure and arrhythmias), chronic liver hepatitis, which can evolve in cirrhosis and, rarely, in hepatocellular carcinoma, endocrine problems (hypogonadism, hypothyroidism, diabetes, hypoparathyroidism), stunted growth, osteoporosis, thrombophilia and pseudoxanthoma elasticum. ${ }^{9}$

9. Vriddhi, Sthana, Kshaya: This implies for the aggravating, static and reliving factors of disease. In short it implies for Upashya and Anupashya. The factors which results in depletion of Dhatus and deterioration of Bala (Immunity) will enhance the disease progress. The use of Antioxidant, Hepatoprotective, and Immunomodulator decrease the progression.

10: Udarkam: Udarkam means the outcome of disease process. According to charaka if Vaidya knows curable and incurable diseases and initiates treatment in time with the full knowledge (about the various aspects of the therapeutics) can certainly accomplish his objective (of curing the disease). ${ }^{10}$ The Udarka of a Vyadhi is determined by considering following features.
(a) Number of prodromal symptoms appearing
(b) Severity of prodromal symptoms
(c) Involvement of Doshas and Dushyas in its Samprapti.
(d) Season
(e) Place
(f) Gati of Doshas 
(g) Afflicted Vyadhimargas

(h) Afflicted organs

(i) Upadravas

(j) Response to medicines

As per the severity of these features, the Vyadhi becomes Sadhya or Asadhya.

11. Namam: Acharyas named the diseases according to its

(1) Pratyatmalinga (Rupa)

(2) Involved Dosha and Dushyas (Samprapti Ghatakas)

(3) Adhisthana

Pratyatmalinga: This is the specific symptom of particular disease. Pratiniyata lakshana and Avyabhichari lakshana are its synonyms. It indicates the Swarupa of Vyadhi. In Thalassemia pratyatmalinga is Panduta (Discoloration of skin) and Raktalpata is the landmark of disease. Due to that features it may be considered under Pandu Roga.

Involvement of Dosha and Dushya: Another criterion of naming is according to the pathogenesis of disease e.g. Rakta Pitta is named after the chiefly involved Dosha and Dushya in the disease. In Thalassemia during the study observe that Vatapitta Prakriti was found predominant it may be due to vitiation of Vata and Pitta along with Sleshmakshaya. Thalassemia may be coming under the Anuvanshika Tridosaja Pandu. Tridoshaja Pandu is the severe form of all the types of Pandu.

Adhistthana: Adhistthana is another criterion for naming a disease. A next criterion in naming a disease is according to its Adhisthtana. Adhisthana of Thalassemia is the Beejabhagavayava, which is responsible for the formation of Rakta-Dhatu. Hence the Vyadhi can also be named as Beejadushtijanya Pandu in Bala.

12. Yogam: Yogam implies planning of treatment i.e. stratagem of therapy. The treatment should be arranged in such a way as to deal with the problems of chronic, life threatening illness. Pravritti and Nivritti comes under treatment protocol. According to Vagbhata the treatment should be arranged in such a way as to deal with the problems of chronic, life threatening illness. Before starting treatment, procedures disease must be studied first. ${ }^{11}$ Thalassemia treatment principals include Nidana Parivarjana, Agni Sandeepana, Pachana, Sroto-anusari Chikitsa, Snehana, Balya, Brimhana, Jeevaneeya, Vayasthapana, Vrishya, Rasayana, Pandu Chikitsa, Apatarpanotha Vyadhi Chikitsa, Dosha Pratyaneeka Chikitsa, Raktadhatu vardhaka and Raktadhatu Sthapaka Chikitsa.

\section{DISCUSSION}

The Beeja Dosha concept of genetic diseases was established very clear in the ancient time and the disease mentioned in the classics. The vitiated Beejabhagavayava of Rakta Dhatu already presents in the offspring but after manifestation of disease, excess intake of Pitta Prakopaka Ahara lead to Dushti of Tridosha but mainly Dushti of Pitta. After taking Pittavardhaka Ahara Ushma, Guna of Pitta increases and Raga (Pittoshma) also affected the same as principle of Sarvada Sarva Bhavanam Samanyam vriddhi Karanam. Raga (Pittosma) is the Guna which can not exist independently in the body and the substances on which it depends is the Rasa. So as per Ayurveda, one can define that when Raga ( $\mathrm{RBCs}+\mathrm{Hb}$ ) is added to Rasa (plasma), Rakta is formed. Raktaja Vyadhis are Tridoshaja, but among the Tridoshas, mainly Pitta is predominant, in Rakta Dushti as maximum Nidanas for Rakta Dushti are Pitta Prakopajanya and the Pitta and Rakta have similar properties and site, so as Pitta gets vitiated, Rakta also becomes vitiated itself. Moolakarana or the essential cause for Thalassemia is the defect in the Globin chain. Defected $\alpha$ and $\beta$ genes are responsible factor of this disease. The causative factors of disease given in the classics are mainly three types Asatmendriyartha Samyoga, Pragyaparadha or Parinama. ${ }^{12}$ The defect in the Globin chain may be due to these factors. The causes of Vikrita Santana mention in the classics are Beeja, Atmakarma, Ashaya (Garbhashaya) and Kala (Time factor) and Matuha Ahara Vihara. These hidden factors must be affecting the Genetic structure of the human body. Due to these characters, Vyadhi becomes almost Pratyakheya in nature. Asadhya nature of genetic disease already 
mentioned in Ayurvedic classics in reference to Kulaja Vikara $)^{13}$ and this disease can be managed by only Nidana Parivarjana (Carrier screening), Pathyabhyasa and by the Rasayana drugs which protect them from the complications.

\section{CONCLUSION}

In Thalassemia due to defective Globin chain synthesis, normal RBCs are not formed and those are formed having very less survival rate. The RBCs destruction occurs in the spleen (Major organ of ReticuloEndothelial system. Charaka and Sushruta have clearly mentioned that the vitiation of all the three Doshas causes Rakta Dushti and thereby Twak become pale in colour. Pathogenesis of Thalassemia (Anukta Vyadhi in Ayurveda) can be understand by Aptopadesha method of examination in mentioned Charaka.

\section{REFERENCES}

1. Shukla V, editor, (2nd ed.). Charaka Samhita of charak, Vimana Sthana: Chapter 4, Verse 6. Varanasi: Chowkhambha Sanskrit Series, 2002; 276.

2. Pandit Hari Sadasiva Sastri Paradakara editor, Ashtanga Hridaya with the commentaries Sarvangasundara of Arundatta and Ayurveda Rasayana of Hemadri, Bhisagacarya; Nidansthan, Chapter 7, Verse 6-7, Chaukhamba Orientalia, Varanasi, Reprint -2000, pg 270

3. Shukla V, editor, (2nd ed.). Charaka Samhita of charak, Shair Sthan: Chapter 3, Verse 17. Varanasi: Chowkhambha Sanskrit Series, 2002; 362.

4. Shukla V, editor, (2nd ed.). Charaka Samhita of charak, Shair Sthan: Chapter 4, Verse 30. Varanasi: Chowkhambha Sanskrit Series, 2002; 378

5. Beta-thalassemia. Accessed on 11 March 2020, Available from- https:/www.orpha.net/ consor/cgibin/OC_Exp.php?Lng $=$ EN\&Expert $=848$

6. Ohene-Frempong, Kwaku, and Elias Schwartz. "Clinical features of thalassemia." Pediatric Clinics of North America 27.2 (1980): 403-420.

7. Williams, T. N., \& Weatherall, D. J. (2012). World distribution, population genetics, and health burden of the hemoglobinopathies. Cold Spring Harbor perspectives in medicine, 2(9), a011692.

8. Tan, G. B., et al. "Evaluation of high-performance liquid chromatography for routine estimation of haemoglobins
A2 and F." Journal of clinical pathology 46.9 (1993): $852-856$

9. Borgna-Pignatti, Caterina, and Maria Rita Gamberini. "Complications of thalassemia major and their treatment." Expert review of hematology 4.3 (2011): 353-366.

10. Sharma RK and Bhagwan Dash. editor, (2nd ed.). Charaka Samhita, Sutra Sthana, Chapter 10, Verse 7-8, English Translation, Reprint. Vol. 4. Varanasi: Chowkhamba Sanskrit Series Office; 2009. pp. 167

11. Dr Ravidutt Tripathi, editor, Ashtanga Samgraha of Vridha Vagbhata, Sutrasthana Chapter 23, Chaukhamba publication 2003, page no 399.

12. Sharma RK and Bhagwan Dash. editor, (2nd ed.). Charaka Samhita, Sutra Sthana, Chapter 11, Verse 43, English Translation, Reprint. Vol. 4. Varanasi: Chowkhamba Sanskrit Series Office; 2009. pp. 187

13. Shukla V, editor, (2nd ed.). Charaka Samhita of charak, chikitsa sthan Sthan: Chapter 6, Verse 57. Varanasi: Chowkhambha Sanskrit Series, 2002;116

\section{Source of Support: Nil Conflict of Interest: None Declared}

How to cite this URL: Kalpana Ladvikar: Ayurvedic Concept Of Knowing Unknown Disease (Anukta Vyadhi) W.S.R. To Thalassemia. International Ayurvedic Medical Journal \{online\} 2020 \{cited October, 2020\} Available from: http://www.iamj.in/posts/images/upload/4876 4880.pdf 